\title{
Evaluation of the Craniofacial Morphology of Egyptian Adults Undergoing Orthodontic Treatment
}

\author{
Mohamed Adel ${ }^{1 *}$, Tetsutaro Yamaguchi ${ }^{1}$, Mohamed Nadim ${ }^{2}$, Daisuke Tomita ${ }^{1}$, Yu Hikita ${ }^{1}$, Takatoshi Nakawaki ${ }^{1}$, Koshu Katayama $^{1}$, Abbadi
} Adel El-Kadi² and Koutaro Maki

${ }^{1}$ Department of Orthodontics, School of Dentistry, Showa University, Ohta-ku, Tokyo, Japan

${ }^{2}$ Department of Orthodontics, Suez Canal University, Egypt

\begin{abstract}
Background: Craniofacial characteristics play an important role in determining the treatment plan for different types of malocclusions. The characteristics of different craniofacial morphologies vary among various populations in different parts of the world. The aim of this study was to identify cephalometric norms in an adult Egyptian population, to compare the values for Egyptian males and females and to descriptively compare the Egyptian norms with the established norms of other populations.
\end{abstract}

Methods: Lateral cephalometric radiographs of 300 adult Egyptians (82 males, 218 females; $18-55$ years) were obtained. The radiographs were traced, and 24 hard-tissue and soft-tissue reference points were localized on the radiographs. Twenty-four angular and seven linear measurements of craniofacial morphology were analyzed with Power Cephalo software (ReazaNet Co., Ltd., Tokyo, Japan), and the results were compared according to gender and populations considered similar to the Egyptian population.

Results: The results showed that the Egyptians had a tendency toward the skeletal Class II with more retrognathic mandibles and more convex profiles in females $(P=0.03$ and 0.016 , respectively). In addition, females had a reduced interincisal angle $(P=0.016)$ and more proclined lower incisors. For the linear dimensions, the males showed a longer anterior cranial base $(P=0.000)$ as well as greater anterior facial height measurements. The tendency toward the skeletal Class II was reflected in the soft tissue measurements with reduced Z-angle values.

Conclusion: Egyptians have distinct craniofacial measurements that are a useful reference for cephalometric values in the diagnosis and treatment planning of orthodontic patients.

Keywords: Lateral cephalometry; Craniofacial morphology; Egyptian cephalometric norms; Orthodontics

\section{Introduction}

Many studies on Ancient and modern Egyptians have concluded that Egyptians have unique common features that are very close to Mediterranean Asians and Europeans as well as Northeast Africans [1-3]. Furthermore, the populations of Europe, North Africa, the African Horn, Mediterranean Asia, and South Asia are physically and biologically considered to have a Caucasian origin [4]. Because every race has characteristic features, craniofacial measurements are considered powerful tools for the determination of the race of unidentified crania [5].

Craniofacial characteristics play an important role in determining the treatment plan for different types of malocclusions. The characteristics of different craniofacial morphologies vary among various populations in different parts of the world [6-9]. Orthodontists need baseline data on the prevalence and characteristics of various types of skeletal deformities in different geographic locations in order to determine proper orientation and treatment possibilities.

Many studies have been conducted in different populations and races to determine the cephalometric standards of different ethnic groups [6-9]. Accordingly, the standards differ among the studies. A comparative cephalometric study of class-III malocclusions of Japanese and British Caucasian adult females showed differences in the skeletal features in lateral cephalograms between the two ethnic groups [10].

Bishara et al. developed cephalometric standards for Egyptian adolescent boys and girls and compared them to a matched sample of North American adolescents. They found that the overall dentofacial morphologies of the Egyptian and Iowa boys and girls were very similar, and there was a tendency toward dental protrusion in the Egyptian groups [11]. Hassan evaluated the cephalometric features of a Saudi population living in the western area of Saudi Arabia and revealed distinct cephalometric features in the Saudis [12]. In their studies on Anatolian Turkish adults who are considered part of the Mediterranean population, Basciftci et al. established cephalometric norms for Turkish men and women and studied the sex differences in this population. They found that the Anatolian Turkish have a long lower anterior facial height with retroclined upper incisors and proclined lower incisors [13]. The Moroccan population, which is a North African population, was examined by Ousehal et al. who established cephalometric norms based on Steiner's analysis, and their results indicated a more retruded mandible and maxilla with large skeletal sagittal discrepancies [14].

Aboul-Azm et al. established craniofacial and soft tissue standards for the Egyptian population. Twenty-two angular measurements, 13 linear measurements, and three ratios were established for the most significant skeletal, dental, and soft-tissue parameters [15]. The aim of the present study was to identify the cephalometric norms in an adult Egyptian population and compare the values of Egyptian males

*Corresponding author: Mohamed Adel, Department of Orthodontics, School of Dentistry, Showa University, Ohta-ku, Tokyo, Japan, Tel: +817014858880; E-mail: mohadel1982@gmail.com

Received April 22, 2016; Accepted May 16, 2016; Published May 25, 2016

Citation: Adel M, Yamaguchi T, Nadim M, Tomita D, Hikita Y, et al. (2016) Evaluation of the Craniofacial Morphology of Egyptian Adults Undergoing Orthodontic Treatment. Dentistry 6: 379. doi:10.4172/2161-1122.1000379

Copyright: (C) 2016 Adel M, et al. This is an open-access article distributed unde the terms of the Creative Commons Attribution License, which permits unrestricted use, distribution, and reproduction in any medium, provided the original author and source are credited. 
and females and descriptively compare the Egyptian norms with the established norms of other populations.

\section{Materials and Methods}

Standardized lateral cephalometric radiographs were taken of 300 Egyptian adult males and females. The subjects were current or former patients of the Orthodontic Department of the Faculty of Dentistry of Suez Canal University. Their age range was 18-55. The sample consisted of 82 males (mean age $=21.0$, standard deviation $=6.8$ ) and 218 females $($ mean age $=21.1$, standard deviation $=6.8$ ). The inclusion criteria were:

- No previous orthodontic or orthopedic treatment.

- No congenital disorder, such as cleft palate, or general physical disease.

Only one patient was excluded from this study because he had cleft lip and palate.

The radiographs were scanned with a HP Scanjet G3110 Photo Scanner (Hewlett Packard Co., Palo Alto, CA, USA). The radiographs were then traced and measured by a single examiner at Showa University in Tokyo with Power Cephalo software (ReazaNet Co., Ltd., Tokyo, Japan) to analyze the craniofacial morphology. A total of 19 hard-tissue and 5 soft-tissue reference points were localized on the radiographs (Tables 1 and 2 and Figure 1), and 24 angular (Table 3) and seven linear (Table 4) measurements were analyzed) [16-18]. The same software was used to correct all of the linear measurements for magnification differences.

To investigate intraoperator error, 55 lateral cephalograms were chosen randomly and re-traced in separate sessions with a two-week interval under identical conditions. The method error was assessed with Dahlberg's formula and paired sample t-tests $[19,20]$.

The initial statistical approach was to provide descriptive statistics of the collected data for the examined craniofacial parameters of the males and females. The gender differences in the cephalometric variables were tested with independent $t$-tests. The data were analyzed with a commercial social science statistical package (SPSS Statistics, Version 23.0; IBM Corporation, Armonk, NY, USA). Statistical significance was tested at $\mathrm{P}<0.05$ and $\mathrm{P}<0.01$.

\section{Results}

The statistical analysis provided a full description of the craniofacial morphology of the Egyptians (Table 5). The results showed that the Egyptians had a tendency toward the skeletal Class II with more retrognathic mandibles and more convex profiles in females $(P=0.03$ and 0.016 , respectively). In addition, females had a reduced interincisal angle $(P=0.016)$ and more proclined lower incisors. For the linear dimensions, the males showed a longer anterior cranial base (N-S, $P$ $=0.000)$ as well as greater anterior facial height measurements. The tendency toward the skeletal Class II was reflected in the soft tissue measurements with reduced $\mathrm{Z}$-angle values.

\section{Discussion}

This study compared the craniofacial measurements of adult Egyptian men and women with the measurements determined by other investigators who previously studied Egyptians and the measurements of investigators who studied other ethnic groups who are thought to be close to the Egyptian race and have the same origin. These results suggest that Egyptians have a distinct craniofacial morphology that is close to that of Caucasians who are thought to be the origin of the Egyptian race.

Egyptian adults have a tendency toward the skeletal Class II with more convex profiles, especially in females. In addition, females

\begin{tabular}{|c|c|c|}
\hline \multicolumn{3}{|r|}{ Hard and soft-tissue points } \\
\hline S & Sella & The center of the sella turcica. \\
\hline $\mathrm{N}$ & Nasion & Situated at the frontonasal suture. \\
\hline Or & Orbitale & The most inferior point on the inferior orbital margin. \\
\hline ANS & $\begin{array}{l}\text { Anterior nasal } \\
\text { spine }\end{array}$ & The apex of the anterior nasal spine. \\
\hline Point A & Subspinale & $\begin{array}{l}\text { The most posterior point on the anterior contour of the } \\
\text { upper alveolar process. }\end{array}$ \\
\hline Is & Incision superius & $\begin{array}{l}\text { The midpoint of the incisal edge of the most } \\
\text { prominent upper central incisor. }\end{array}$ \\
\hline As & Apex superius & $\begin{array}{l}\text { The apex of the root of the most prominent upper } \\
\text { central incisor. }\end{array}$ \\
\hline li & Incision inferius & $\begin{array}{l}\text { The midpoint of the incisor edge of the most } \\
\text { prominent lower central incisor. }\end{array}$ \\
\hline $\mathrm{Ai}$ & Apex inferius & $\begin{array}{l}\text { The apex of the root of the most prominent lower } \\
\text { central incisor. }\end{array}$ \\
\hline Point B & supramentale & $\begin{array}{l}\text { The most posterior point on the anterior contour of the } \\
\text { lower alveolar process. }\end{array}$ \\
\hline Pog & Pogonion & The most anterior point on the mandibular symphysis. \\
\hline Gn & Gnathion & $\begin{array}{l}\text { The most anteroinferior point on the symphysis of the } \\
\text { chin constructed from a line drawn perpendicular to } \\
\text { the line connecting the menton and pogonion. }\end{array}$ \\
\hline $\mathrm{Me}$ & Menton & The most inferior point on the mandibular symphysis. \\
\hline Go & Gonion & $\begin{array}{l}\text { A point on the curvature of the angle of the mandible } \\
\text { located by bisecting the angle formed by lines tangent } \\
\text { to the posterior ramus and the inferior border of the } \\
\text { mandible. }\end{array}$ \\
\hline $\operatorname{Ar}$ & Articulare & $\begin{array}{l}\text { The point at the junction of the posterior border of the } \\
\text { ramus and the inferior border of the posterior cranial } \\
\text { base (occipital bone). }\end{array}$ \\
\hline $\mathrm{Cd}$ & Condylion & The most superoposterior point on the condylar head. \\
\hline Po & Porion & $\begin{array}{l}\text { The most superior point on the external auditory } \\
\text { meatus. }\end{array}$ \\
\hline Ptm & Pterygomaxillare & $\begin{array}{l}\text { The intersection between the nasal floor and the } \\
\text { posterior contour of the maxilla. }\end{array}$ \\
\hline PNS & $\begin{array}{l}\text { Posterior nasal } \\
\text { spine }\end{array}$ & The apex of the posterior nasal spine. \\
\hline PRN & Pronasale & The most anterior point of the nose. \\
\hline Ls & Labrale superius & $\begin{array}{l}\text { The most prominent point on the prolabium of the } \\
\text { upper lip. }\end{array}$ \\
\hline $\mathrm{Li}$ & Labrale inferius & $\begin{array}{l}\text { The most prominent point of the prolabium of the } \\
\text { lower lip. }\end{array}$ \\
\hline Ils & $\begin{array}{l}\text { Inferior labial } \\
\text { sulcus }\end{array}$ & $\begin{array}{l}\text { The point of greatest concavity in the midline of the } \\
\text { lower lip between Li and Pog'. }\end{array}$ \\
\hline Pog' & $\begin{array}{l}\text { Soft tissue } \\
\text { pogonion }\end{array}$ & The most prominent point on the chin. \\
\hline
\end{tabular}

Table 1: Hard and soft-tissue points reference.

Frankfort horizontal line A line drawn from the superior point of the anatomic (FH) porion to the inferior point of the orbitale.

Occlusal plane (OP) The line of best intercuspation between the premolars and molars.

Sella-Nasion plane (SN) A line from the Sella to Nasion representing the anterior cranial base.

Mandibular plane (MP) A line passing from the gonion to throat gnathion on

Z-line Chin-lip profile line.

Facial line N-Pog line.

Ramus line Ar-Go line.

Table 2: Linear reference points. 


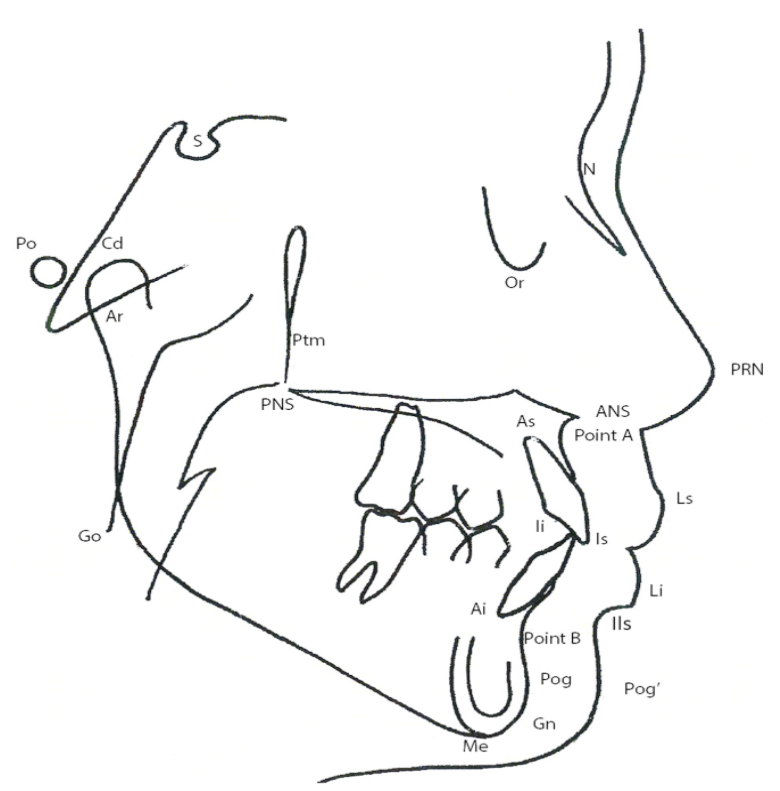

Figure 1: Hard tissue and soft tissue points.

have reduced interincisal angles and more proclined lower incisors. For the linear dimensions, the males showed longer anterior cranial bases as well as greater anterior facial height measurements. The tendency toward the skeletal Class II was reflected in the soft-tissue measurements with reduced $\mathrm{Z}$-angle values.

All of the subjects were adults who had lateral cephalometric radiographs taken for diagnostic purposes. Therefore, the study had some sampling bias. The sample was taken randomly without considering any selection criteria that were based on the occlusal evaluations or facial aesthetics, which helped decrease the sampling subjectivity. Hence, the sample was more representative of the normal distribution of the different craniofacial morphologies of the Egyptian population.

Aboul-Azm et al. selected Egyptian subjects with normal occlusion and harmonious facial features [15]. Similarly, Bishara et al. selected only 90 Egyptian school children who had Class-I molar and canine relationships and no apparent skeletal discrepancies out of 500 Egyptian schoolchildren [11]. Alcalde et al. selected their sample from subjects with Class-I occlusions and good facial symmetry [7].

However, only a few studies have used random samples that were more representative of the population. For instance, Aldrees selected his sample from the records of orthodontic patients without considering their occlusion status or facial characteristics [21].

Although random samples are difficult to obtain due to ethical reasons and radiological restrictions, they are considered to have less bias or subjectivity from selections that are based on a harmonious profile and normal occlusion, for example.

Furthermore, the sample size consisted of 299 adult patients (218 females and 81 males) who were selected for the cephalometric investigation, and this was a relatively large sample size. Aboul-Azm et al. conducted their cephalometric investigations on 100 females and 100 males [15], whereas Bishara et al. used a sample of 90 (39 boys and 51 girls) subjects in their study [11]. A large sample size is more representative of the population, as the influence of outliers or extreme observations are limited. A sufficiently large sample size is also necessary to produce results among variables that are significantly different [22].

Using Dahlberg's formula and paired sample t-tests, statistically significant differences were detected in duplicate determinations of the linear measurements: upper anterior face height (N-ANS) and the distance between the most anteriorly placed point and the nasionsupramentale line (L1-NB), as shown in Table 6. Poor identification of the nasion (N, as a common point), Anterior Nasal Spine (ANS), supramentale (point $\mathrm{B}$ ), or the incision inferius might have been the cause for these differences.

This sample consisted of only adult subjects. This was similar to Aboul-Azm et al.'s study [15]. In contrast, Bishara et al. examined adolescent boys and girls [11]. The use of adult subjects is considered

\begin{tabular}{|c|c|}
\hline \multicolumn{2}{|l|}{ Angular measurement } \\
\hline SNA & $\begin{array}{l}\text { Sella-nasion-point } A \text { angle (representing maxillary } \\
\text { protrusion in relation to the anterior cranial base). }\end{array}$ \\
\hline SNB & $\begin{array}{l}\text { Sella-nasion-point B angle (representing mandibular } \\
\text { protrusion in relation to the anterior cranial base). }\end{array}$ \\
\hline ANB & $\begin{array}{l}\text { Point A-nasion-point B (position of the jaws relative to } \\
\text { each other). }\end{array}$ \\
\hline $\mathrm{FH}$ to $\mathrm{SN}$ & The angle between the $\mathrm{FH}$ plane and SN line. \\
\hline Facial angle & $\begin{array}{l}\text { The angle between the facial line (N-Pog) and } \mathrm{FH} \\
\text { plane. }\end{array}$ \\
\hline Convexity & The intersection of line N-point A to Point A-Pog. \\
\hline A-B Plane & The angle between the A-B line and N-Pog line. \\
\hline Mandibular plane & The angle between the MP and FH plane. \\
\hline Gonial angle & The angle formed between the ramus line and the MP. \\
\hline Y-axis & $\begin{array}{l}\text { The angle formed by intersection of the N-Gn line and } \\
\text { FH plane. }\end{array}$ \\
\hline Ramus inclination & $\begin{array}{l}\text { The angle formed between the ramus line and } \mathrm{FH} \\
\text { plane. }\end{array}$ \\
\hline FMA & The angle between the MP and FH plane. \\
\hline IMPA & $\begin{array}{l}\text { The angle formed by the intersection of the MP with a } \\
\text { line passing through the incisal edge and the apex of } \\
\text { the root of the mandibular incisor. }\end{array}$ \\
\hline FMIA & $\begin{array}{l}\text { The angle between the } \mathrm{FH} \text { with a line passing through } \\
\text { the incisal edge and the apex of the root of the } \\
\text { mandibular incisor. }\end{array}$ \\
\hline Interincisal angle & $\begin{array}{l}\text { The angle formed between lines passing through the } \\
\text { incisal edge and the apex of the root of the maxillary } \\
\text { and mandibular central incisors. }\end{array}$ \\
\hline $\mathrm{U}-1$ to $\mathrm{FH}$ plane & $\begin{array}{l}\text { The angle formed by the intersection of the } \mathrm{FH} \text { with a } \\
\text { line passing through the incisal edge and the apex of } \\
\text { the root of the maxillary incisor. }\end{array}$ \\
\hline U-1 to SN Plane & $\begin{array}{l}\text { The angle formed by the intersection of the } \mathrm{SN} \text { with a } \\
\text { line passing through the incisal edge and the apex of } \\
\text { the root of the maxillary incisor. }\end{array}$ \\
\hline L-1 to mandibular plane & $\begin{array}{l}\text { The angle formed by the intersection of the MP with a } \\
\text { line passing through the incisal edge and the apex of } \\
\text { the root of the mandibular incisor. }\end{array}$ \\
\hline $\mathrm{U}-1$ to $\mathrm{NA}$ & $\begin{array}{l}\text { The angle formed by the intersection of the } \mathrm{N} \text {-point } \mathrm{A} \\
\text { line with a line passing through the incisal edge and } \\
\text { the apex of the root of the mandibular incisor. }\end{array}$ \\
\hline L-1 to NB & $\begin{array}{l}\text { The angle formed by the intersection of the } \mathrm{N} \text {-point } \mathrm{A} \\
\text { line with a line passing through the incisal edge and } \\
\text { the apex of the root of the maxillary incisor. }\end{array}$ \\
\hline Z angle & $\begin{array}{l}\text { The angle between the Z-line (chin-lip profile line) and } \\
\text { FH. }\end{array}$ \\
\hline Nasolabial angle & $\begin{array}{l}\text { The angle formed by the intersection of a columella } \\
\text { tangent and an Ls tangent. }\end{array}$ \\
\hline Mentolabial angle & The angle between Li, Ils and Pog'. \\
\hline Occlusal plan angle & The angle formed between the OP and FH plane. \\
\hline
\end{tabular}

Table 3: Angular measurements. 


\begin{tabular}{|c|l|}
\hline $\begin{array}{c}\text { Linear } \\
\text { measurements }\end{array}$ & \\
\hline N-S & Anterior cranial base length. \\
\hline N-Me & Total anterior face height. \\
\hline N-ANS & Upper anterior face height. \\
\hline ANS-Me & Lower anterior face height. \\
\hline U1-NA & $\begin{array}{l}\text { The distance between the most anteriorly placed point and the } \\
\text { NA line. }\end{array}$ \\
\hline L1-NB & $\begin{array}{l}\text { The distance between the most anteriorly placed point and the } \\
\text { NB line. }\end{array}$ \\
\hline Wits & $\begin{array}{l}\text { Distance between the AO and BO points on the occlusal } \\
\text { plane. (The AO point is formed by point A perpendicular to } \\
\text { the occlusal plane, and the BO point is formed by point B } \\
\text { perpendicular to the occlusal plane.) }\end{array}$ \\
\hline
\end{tabular}

Table 4: Linear measurements.

\begin{tabular}{|c|c|c|c|c|c|}
\hline \multirow{2}{*}{ Variable } & \multicolumn{2}{|c|}{ Male } & \multicolumn{2}{|c|}{ Female } & \multirow{2}{*}{$\begin{array}{c}P \text { value } \\
\text { (Gender difference) }\end{array}$} \\
\hline & Mean & SD & Mean & SD & \\
\hline SNA & 82.1 & 4.5 & 82 & 3.8 & 0.736 \\
\hline SNB & 78.9 & 5.6 & 77.6 & 4.1 & $.030^{*}$ \\
\hline ANP & 3.5 & 3.5 & 4.4 & 2.7 & $.021^{*}$ \\
\hline FH-SN & 4.9 & 3.9 & 6.7 & 3.4 & $.000^{* *}$ \\
\hline Facial angle & 84.2 & 4.6 & 84.8 & 3.4 & 0.178 \\
\hline Convexity & 5.9 & 7.3 & 8 & 6.1 & $.016^{\star}$ \\
\hline A-P plane & -5.3 & 4.6 & -6.5 & 3.8 & $.029^{*}$ \\
\hline Mandibular plane & 30.6 & 5.7 & 31.1 & 5.4 & 0.411 \\
\hline Gonial Angle & 120.9 & 6 & 120.4 & 6.2 & 0.676 \\
\hline Y-axis & 65 & 4.8 & 63.9 & 4.3 & 0.054 \\
\hline Remus inclination & 89.6 & 4.7 & 90.6 & 5.2 & 0.198 \\
\hline FMA & 30.6 & 5.7 & 31.1 & 5.4 & 0.411 \\
\hline IMPA & 92.9 & 9 & 94.9 & 8.5 & 0.093 \\
\hline FMIA & 56.4 & 9.2 & 53.9 & 8.7 & $.031^{*}$ \\
\hline Interincisal angle & 125.6 & 12.9 & 121.3 & 12.5 & $.016^{*}$ \\
\hline U1-FH & 110.8 & 9.2 & 112.6 & 8.1 & 0.179 \\
\hline U1-SN & 105.9 & 9.8 & 105.7 & 8.6 & 0.658 \\
\hline L1-Mandibular plane & 92.9 & 9 & 94.9 & 8.5 & 0.093 \\
\hline U1-NA & 23.8 & 8.4 & 23.8 & 7.9 & 0.828 \\
\hline L1-NB & 27.1 & 7.6 & 30.4 & 7.8 & $.001^{* *}$ \\
\hline$Z$ angle & 65.3 & 8.7 & 65.3 & 8.4 & 0.97 \\
\hline Nasolabial angle & 100.65 & 13.7 & 100.7 & 12 & 0.177 \\
\hline Mentolabial angle & 121.21 & 14.2 & 124.31 & 14.4 & 0.394 \\
\hline Occlusal plane & 9.8 & 4.9 & 10.1 & 4.3 & 0.664 \\
\hline $\mathrm{N}-\mathrm{S}$ & 66.6 & 7.8 & 63 & 5.3 & $.000^{* *}$ \\
\hline $\mathrm{N}-\mathrm{Me}$ & 120.6 & 10.1 & 113.6 & 9.2 & $.000^{* *}$ \\
\hline N-ANS & 52.8 & 5.3 & 50.5 & 4.8 & $.001^{* *}$ \\
\hline ANS-Me & 69.4 & 6.9 & 65.3 & 7.2 & $.000^{* *}$ \\
\hline U1-NA & 5.9 & 3.2 & 5.6 & 2.9 & 0.346 \\
\hline L1-NB & 6.6 & 3.2 & 7.3 & 3 & 0.101 \\
\hline Wits & 4.1 & 3.9 & 3.4 & 2.4 & $.046^{*}$ \\
\hline
\end{tabular}

Table 5: Descriptive statistics of the craniofacial morphology of Egyptian males ( $n$ $=81)$ and females $(n=218)$.

advantageous as it rules out growth-related variations in the hard and soft tissue. However, this study used computer software for the cephalometric investigations, whereas manual tracing was used in the studies of Bishara et al. and Aboul-Azm et al. [11,15]. The computer software was used as it produces more reliable results and consistent angular and linear measurements.

Regarding the craniofacial measurements, the males had a Point
A-Nasion-Point B (ANB) measurement of 3.5 degrees, which was more than the 2.75 degrees found by Aboul-Azm et al. and close to the 3.6 degrees found by Bishara et al. $[11,15]$. These minor differences might have been due to the use of different cephalometric investigational methods among the different studies. The value for the Wits analysis was $4.1 \mathrm{~mm}$, which was higher than the $-0.47 \mathrm{~mm}$ and $0.7 \mathrm{~mm}$ obtained by Aboul-Azm et al. and Bishara et al., respectively, which indicated a tendency toward bimaxillary protrusion $[11,15]$. This value was supported by the high values of the angle of convexity and A-B plane, which were 5.9 degrees and -5.3 degrees, respectively. The value of the facial angle was 84.2 degrees, which was less than the value obtained by Aboul-Azm et al. which was 87.1 degree, but almost similar to the 84 degrees obtained by Bishara et al. [11,15]. The mandibular plane angle was 30.6 degrees, which was higher than the 25.41 degrees found by Aboul-Azm et al. and which indicated a greater vertical dimension [15]. This finding was supported by the higher Y-axis angle, which was 65 degrees, which was more than the 61.3 degrees obtained by Aboul-Azm et al. [15]. The length of the anterior cranial base, which was indicated by the linear measurement (N-S), was $66.6 \mathrm{~mm}$, which was close to the $66.2 \mathrm{~mm}$ obtained by Bishara et al. [11]. The reason that the adults and adolescent subjects have almost similar anterior cranial base lengths might be that the time of closure of the spheno-occipital synchondrosis ranges from 13-15 years and there is no more endochondral bone

\begin{tabular}{|c|c|c|c|c|}
\hline \multirow{2}{*}{$\begin{array}{c}\text { Variable } \\
\text { SNA }\end{array}$} & \multicolumn{2}{|l|}{ Mean } & \multirow{2}{*}{$\begin{array}{c}\begin{array}{c}\text { Two-tailed } \\
\text { significance }\end{array} \\
0.921\end{array}$} & \multirow{2}{*}{$\begin{array}{c}\begin{array}{c}\text { Dahlberg's } \\
\text { method error }\end{array} \\
0.004\end{array}$} \\
\hline & 81.8 & 81.8 & & \\
\hline SNB & 77.9 & 77.8 & 0.759 & 0.004 \\
\hline ANP & 3.9 & 3.9 & 0.988 & 0.101 \\
\hline FH-SN & 6.2 & 6 & 0.246 & 0.042 \\
\hline Facial angle & 84.6 & 84.4 & 0.057 & 0.005 \\
\hline Convexity & 7.1 & 7.2 & 0.415 & 0.064 \\
\hline A-P plane & -5.8 & -5.6 & 0.368 & -0.055 \\
\hline Mandibular plane & 33.7 & 33.9 & 0.108 & 0.0125 \\
\hline Gonial angle & 124.9 & 124.8 & 0.803 & 0.008 \\
\hline Y-axis & 65.6 & 65.7 & 0.23 & 0.006 \\
\hline Ramus Inclination & 88.8 & 89.1 & 0.339 & 0.01 \\
\hline FMA & 33.7 & 33.9 & 0.108 & 0.012 \\
\hline IMPA & 91.3 & 91.3 & 0.834 & 0.009 \\
\hline FMIA & 54.9 & 54.8 & 0.552 & 0.015 \\
\hline Interincisal angle & 125.6 & 125.5 & 0.692 & 0.009 \\
\hline U1-FH & 109.3 & 109.3 & 0.992 & 0.009 \\
\hline U1-SN & 103 & 103.2 & 0.556 & 0.009 \\
\hline L1-Mandibular plane & 91.3 & 91.3 & 0.828 & 0.009 \\
\hline U1-NA & 21.3 & 21.5 & 0.499 & 0.047 \\
\hline L1-NB & 29.2 & 29.1 & 0.796 & 0.03 \\
\hline Z angle & 66.5 & 66.7 & 0.458 & 0.013 \\
\hline Nasolabial angle & 100.8 & 101 & 0.814 & 0.01 \\
\hline Mentolabial angle & 129.4 & 130.1 & 0.452 & 0.009 \\
\hline Occlusal plane & 10.9 & 11 & 0.526 & 0.284 \\
\hline $\mathrm{N}-\mathrm{S}$ & 61.4 & 61.6 & 0.535 & 0.017 \\
\hline $\mathrm{N}-\mathrm{Me}$ & 115.4 & 116 & 0.17 & 0.016 \\
\hline N-ANS & 51.2 & 51.6 & $0.043^{*}$ & 0.017 \\
\hline ANS-Me & 66.2 & 66.2 & 0.886 & 0.024 \\
\hline U1-NA & 4.9 & 4.9 & 0.525 & 0.226 \\
\hline L1-NB & 6.6 & 6.4 & $0.024^{*}$ & 0.05 \\
\hline Wits & 3.3 & 3.5 & 0.383 & 0.468 \\
\hline
\end{tabular}

Table 6: Duplicate determinations of the measurements in the cephalometric radiographs. 
growth after this age [23]. More proclined upper and lower incisor teeth were indicated by the interincisal angle of 125.6 degrees, which contrastes with the values obtained by Aboul-Azm et al. and Bishara et al., which were 127.21 degrees and 127 degrees, respectively $[11,15]$. Moreover, the males had a Z-angle of 65.3, which was much lower than the 71.65 degrees found by Aboul-Azm et al. [15]. The decreased value of the $\mathrm{Z}$-angle indicated profile convexity (more protrusive lips), which can also be indicated by the increases in the angle of convexity and A-B plane [24].

However, the craniofacial measurements of the females showed that the ANB angle was 4.4 degrees. This value was higher than the values obtained by Aboul-Azm et al. and Bishara et al., which were 2.52 degrees and 3.2 degrees, respectively $[11,15]$. The SNA value was 82 degrees, which was close to the 81.06 degrees and 82.7 degrees obtained by Aboul-Azm et al. and Bishara et al., respectively $[11,15]$. However, the SNB value was 77.6 degrees, which was lower than the 78.5 degrees and 79.5 degrees found by Aboul-Azm et al. and Bishara et al., respectively, indicating a more retrognathic mandible $[11,15]$. This was confirmed by the facial angle, which was 84.8 degrees, in contrast to the 87.6 obtained by Aboul-Azm et al. [15]. The Wits measurement of $3.4 \mathrm{~mm}$ was higher than the $-1.16 \mathrm{~mm}$ and $-0.1 \mathrm{~mm}$ reported by Aboul-Azm et al. and Bishara et al. in their studies $[11,15]$. The angle of convexity for the females in this study was 8 degrees, which contrasted with the much smaller angle of 3.5 degrees reported by Aboul-Azm et al. [15].

The gender comparison showed a statistically significant difference in mandibular prognathism (SNB), with males showing more prognathic mandibles $(\mathrm{P}=0.030)$. In addition, the measurements of the intermaxillary protrusion (ANB) revealed a trend toward the ClassII skeletal pattern for females $(\mathrm{P}=0.021)$. This was confirmed by the statistically significant difference in the angle of convexity and A-B plane $(\mathrm{P}=0.016$ and $\mathrm{P}=0.029$, respectively), which indicated a more convex profile in females. One reason could be that the mandible grows more in males than in females, which gives the males a more straight profile than the convex profile of the females [25]. Similarly, AboulAzm et al. found that the mandibular base was more retrognathic in females, as indicated by the SNB angle, which contrasted with the findings of Bishara et al. who found no significant difference between males and females $[11,15]$. In addition, the anterior cranial base length $(\mathrm{N}-\mathrm{S})$ was significantly larger in males $(\mathrm{P}=0.000)$. The linear face height measurements (N-Me, N-ANS, and ANS-Me) were also significantly larger in males $(\mathrm{P}=0.000), \mathrm{P}=0.000, \mathrm{P}=0.001$, and $\mathrm{P}=0.000$, respectively). This was expected because males are generally larger than females [26].

The upper and lower incisors were significantly more upright in males than in females $(\mathrm{P}=0.016)$. The angular measurements of the lower incisor to the mandibular plane, the lower incisor to the NB line, and the lower incisor to the $\mathrm{FH}$ plane all indicated more protrusion of the lower incisors in females than in males. The difference was significant for the lower incisor to NB line angle $(\mathrm{P}=0.01)$ and the lower incisor to the $\mathrm{FH}$ plane angle $(\mathrm{P}=0.031)$. The reason might have been the compensatory mechanisms of the lower incisors due to the more retrusive position of the mandible.

In our study, we measured the nasolabial angle and the mentolabial angle, which have not been measured by Aboul-Azm et al. and Bishara et al. in their studies $[11,15]$. The nasolabial angle can be changed by orthodontic or surgical treatment as it depends on the anteroposterior position or inclination of the upper anterior teeth [27]. The nasolabial angle should be $102 \pm 8$ degrees regardless to whether the orthodontic or surgical correction is indicated [28]. This is important in determining the upper lip position during treatment planning, especially if extraction or orthognathic surgeries are part of the plan. The mentolabial angle is greatly affected by the skeletal morphology and position and angulation of lower incisors. The mean value is $122 \pm 11.7$ but more pronounced angle can bee seen in Class II and vertical maxillary deficiency cases. On the other hand, more uprighted lower incisors tend to enlarge the angle [27-29]. In our study, the nasolabial angle was 100.65 for males and 100.70 for females, whereas the mentolabial angle was 121.21 for males and 124.31 for females with no significant difference between males and females $(\mathrm{P}=0.177$ and $\mathrm{P}=0.394$, respectively $)$.

As mentioned previously, the Egyptian race is close to Mediterranean Asians, Europeans, and North Africans, which are Caucasian in origin [1-4]. Comparison of the findings of this study to those of Basciftci et al. on Anatolian Turkish adults that represent the population of Mediterranean Asia, Ousehal et al. on Moroccan subjects who represent the North African population, and Caucasian subjects show a high degree of similarity among these populations $[13,14,30]$. For the anteroposterior skeletal relationship, the mean value of the SNA for the Egyptians in this study was 82.09 degrees, which was close to the 82.57 degrees and 82.2 degrees of the Anatolian Turkish subjects and Caucasian subjects, respectively, but a little more than the 80.88 degrees of the Moroccan subjects $[13,14,30]$. Furthermore, the SNB value was 77.9 degrees, which was similar to the value of the Moroccans and close to the 78.2 degrees of the Caucasians but less than the 79.9 degrees of the Turkish subjects $[13,14,30]$. For the ANB angle, the values were almost the same for the Egyptian and Caucasian subjects, which were 4.1 degrees and 4 degrees, respectively [30]. However, the Moroccans and Turks showed reduced values, which were 3.17 degrees and 2.65 degrees, respectively $[13,14]$. These similarities among these populations support the above-mentioned theory about the origin of the Egyptian race. These minor differences might be attributed to the effect of migration to the area of the Nile valley and to the environmental changes that happened over time, especially the climatic changes [31].

\section{Conclusions}

The outcomes of this study demonstrate the following:

- Egyptians have distinct craniofacial measurements, which are close to the measurements of Mediterranean Asians, Europeans, and North Africans, which are Caucasian in origin.

- The resulting data are a useful reference for the cephalometric values of Egyptian populations for use in clinical examinations and planning for orthodontic and orthognathic treatments together with the patient's need and desires.

- The results showed both linear and angular differences in craniofacial morphology between males and females.

\section{References}

1. Brace CL, Tracer DP, Yaroch LA, Robb J, Brandt K, et al. (1993) Clines and clusters versus "Race:" a test in ancient Egypt and the case of a death on the Nile. Yearb Phys Anthropol 36: 1-31.

2. Poloni ES, Semino O, Passarino G, Santachiara-Benerecetti AS, Dupanloup I et al. (1997) Human genetic affinities for Y-chromosome P49a,f/Taql haplotypes show strong correspondence with linguistics. Am J Hum Genet 61: 1015-1035.

3. Bosch E, Calafell F, Pérez-Lezaun A, Comas D, Mateu E, et al. (1997) Population history of north Africa: evidence from classical genetic markers. Hum Biol 69: 295-311

4. Coon CS (1993) The Races of Europe. New York, NY: The Macmillan Company pp: 400-401. 
Citation: Adel M, Yamaguchi T, Nadim M, Tomita D, Hikita Y, et al. (2016) Evaluation of the Craniofacial Morphology of Egyptian Adults Undergoing Orthodontic Treatment. Dentistry 6: 379. doi:10.4172/2161-1122.1000379

5. Snow CC, Hartman S, Giles E, Young FA (1979) Sex and race determination of crania by calipers and computer: a test of the Giles and Elliot discriminant functions in 52 forensic science cases. J Forensic Sci 24: 448-460.

6. Downs WB (1948) Variations in facial relationships; their significance in treatment and prognosis. Am J Orthod 34: 812-840.

7. Alcalde RE, Jinno T, Pogrel MA, Matsumura T (1998) Cephalometric norms in Japanese adults. J Oral Maxillofac Surg 56: 129-134.

8. Nanda R, Nanda RS (1969) Cephalometric study of the dentofacial complex of North Indians. Angle Orthod 39: 22-28.

9. Drummond RA (1968) A determination of cephalometric norms for the Negro race. Am J Orthod 54: 670-682.

10. Ishii N, Deguchi T, Hunt NP (2002) Craniofacial differences between Japanese and British Caucasian females with a skeletal Class III malocclusion. Eur J Orthod 24: 493-499.

11. Bishara SE, Abdalla EM, Hoppens BJ (1990) Cephalometric comparisons of dentofacial parameters between Egyptian and North American adolescents. Am J Orthod Dentofacial Orthop 97: 413-421.

12. Hassan $\mathrm{AH}$ (2006) Cephalometric norms for saudi adults living in the western region of Saudi Arabia. Angle Orthod 76: 109-113.

13. Basciftci FA, Uysal T, Buyukerkmen A (2004) Craniofacial structure of Anatolian Turkish adults with normal occlusions and well-balanced faces. Am J Orthod Dentofacial Orthop 125: 366-372.

14. Ousehal L, Lazrak L, Chafii A (2012) Cephalometric norms for a Moroccan population. Int Orthod 10: 122-134.

15. Aboul-Azm SF, Enany NM, Fahmy MA, Tamish NO, Abdallah HE (1984) The Alexandria Analysis: Radiographic Cephalometric Standards for Egyptian Adults. Alexandria Dent J 9: 1-8.

16. Yeong P, Huggare J (2004) Morphology of Singapore chinese. Eur J Orthod 26: $605-612$

17. Upadhyay RB, Upadhyay J, Agrawal P, Rao NN (2012) Analysis of gonial angle in relation to age, gender, and dentition status by radiological and anthropometric methods. J Forensic Dent Sci 4: 29-33.
18. Jacobson A, Jacobson $R$ (2006) Radiograohic Cephalometry from Basics to 3-D Imaging. Second Edition, New Malden, Surrey, UK: Quintessence Publishing Co, Inc. pp: 45-135.

19. Dahlberg G (1940) Statistical Methods for Medical and Biological Students. $\mathrm{Br}$ Med J 2: 358-359.

20. Harris EF, Smith RN (2009) Accounting for measurement error: a critical but often overlooked process. Arch Oral Biol 54 Suppl 1: S107-117.

21. Aldrees AM (2012) Pattern of skeletal and dental malocclusions in Saudi orthodontic patients. Saudi Med J 33: 315-320.

22. Patel MX, Doku V, Tennakoon $L$ (2003) Challenges in recruitment of research participants. Adv Psychiatr Treat 9: 229-238.

23. Bishara SE (2001) Textbook of Orthodontics. Philadelphia, PA: Saunders pp 43-51.

24. Rehan A, Iqbal Q, Ayub A, Ahmed I (2013) Soft Tissue Analysis In Class I and Class II skeletal Malocclusion In Patients Reporting to Department of Orthodontics, Khyber College of Dentistry, Peshawar. Pakistan Oral Dent $J$ 34: $87-90$.

25. Ochoa BK1, Nanda RS (2004) Comparison of maxillary and mandibular growth Am J Orthod Dentofacial Orthop 125: 148-159.

26. Premkumar S (2011) Textbook of Craniofacial Growth. First Edition, New Delhi: Jaypee Brothers Medical: 247-249.

27. Anic-Milosevic S, Lapter-Varga M, Slaj M (2008) Analysis of the soft tissue facial profile by means of angular measurements. Eur J Orthod 30: 135-140.

28. Bergman RT (1999) Cephalometric soft tissue facial analysis. Am J Orthod Dentofacial Orthop 116: 373-389.

29. Burstone CJ (1967) Lip posture and its significance in treatment planning. Am J Orthod 53: 262-284.

30. Tecco S, Festa F (2007) Cervical spine curvature and craniofacial morphology in an adult Caucasian group: a multiple regression analysis. Eur J Orthod 29: 204-209.

31. Keita SOY, Boyce AJ (2014) Genetics, Egypt, and History: Interpreting Geographical Patterns of $Y$ Chromosome Variation. History in Africa 32: 221 246. 